\title{
Preventative Root-Collar Excavation Reduces Peach Tree Mortality Caused By Armillaria Root Rot On Replant Sites
}

\author{
Sarah. B. Miller, ${ }^{1}$ Ksenija Gasic, ${ }^{1}$ Gregory L. Reighard, ${ }^{1}$ William G. Henderson, ${ }^{2}$ Phillip A. Rollins, ${ }^{2}$ Michael Vassalos, ${ }^{3}$ \\ and Guido Schnabel ${ }^{1, \dagger}$ \\ ${ }^{1}$ Department of Plant and Environmental Sciences, Clemson University, Clemson, SC 29634, U.S.A. \\ ${ }^{2}$ Cooperative Extension Service, Clemson University, Clemson, SC 29634, U.S.A. \\ ${ }^{3}$ Department of Agricultural Science, Clemson University, Clemson, SC 29634, U.S.A.
}

\begin{abstract}
In the southeastern United States, Armillaria root rot (ARR) is caused by Desarmillaria tabescens and has become the primary cause of premature mortality in peach orchards. Most rootstocks used in commercial orchards are susceptible and management options are limited. A postinfection practice known as root-collar excavation (RCE), which involves permanent removal of the soil from the base of the trunk, has been shown to improve yields and prolong the productive life of symptomatic trees. However, symptomatic trees already have an advanced infection at the base of the trunk. This study evaluated the efficacy of preventative $\mathrm{RCE}$ on the progression of tree mortality in two orchards that were planted in infested replant sites. To provide convincing data for growers, the study was carried out in a commercial orchard and an experimental orchard for 8 years. Furthermore, representative enterprise budgets and net present value (NPV) analysis were utilized to compare the profitability of the two approaches. Trees were planted shallow on berms ( 45 by

mortality in the "Grower Standard" treatment was first observed in year 4 and increased $12.7 \%$ on average per year thereafter. At the commercial orchard, tree mortality in the RCE treatment was first observed in year 7 and increased $1.9 \%$ on average thereafter, while tree mortality in the Grower Standard treatment first appeared in year 5 and increased $4.3 \%$ on average thereafter. The delayed onset of ARR-associated tree mortality and the lower annual tree mortality rate in the RCE treatment led to higher NPVs in both locations. There were no negative effects on yield or fruit quality. However, the new planting system can create horticultural challenges, including the formation of a proper berm, uneven ground around the tree interfering with tree care and harvest, increased erosion due to channeling of rainwater, and increased rootstock suckering. The RCE is a valid option for southeastern growers needing to manage high ARR disease pressure on replant sites or on sites only recently cleared from ARR-infected forest land.
\end{abstract} $90 \mathrm{~cm}$ ) to facilitate RCE with hoes and AirSpade 2 years later. Tree mortality in the RCE treatment of the experimental orchard was first observed in year 6 and increased $8 \%$ on average per year thereafter. In contrast, tree
Keywords: cultural and biological practices, disease management, fruit, fungi, tree fruits, yield loss and economic impacts
Armillaria root rot (ARR), also known as oak root rot, is a major threat to many stone fruit and nut crops throughout the United States. In the southeastern United States, ARR is caused by the basidiomycete fungus Desarmillaria tabescens (Scop.) R. A. Koch \& Aime comb. nov. (synonyms Armillaria tabescens and Clitocybe tabescens) (Koch et al. 2017) and has become the leading cause of premature peach (Prunus persica) tree decline (Rhoads 1950; Schnabel et al. 2005). Similar to other virulent Armillaria spp., D. tabescens spreads via root-to-root contact rather than via rhizomorphs (Rhoads 1945). Conservative mortality estimates range from 3 to $4 \%$ of the region's peach trees each year, which amounts to $\$ 8$ million annually according to the Georgia and South Carolina Peach Councils (personal communication).

${ }^{\dagger}$ Corresponding author: G. Schnabel; schnabe@clemson.edu

Funding: This research was funded by Multistate Specialty Crop Block Grant from the United States Department of Agriculture (USDA) Agriculture Marketing Service Specialty Crop Multistate Project, "Short and long-term solutions for Armillaria root rot in Prunus" (USDA-AMS-SCMP-2015-10.170) and by the Clemson University Experimental Station technical contribution number 6784 . This material is based upon work supported by USDA National Institute of Food and Agriculture, under project number SC-1700501.

The author(s) declare no conflict of interest.

Accepted for publication 31 January 2020.

(C) 2020 The American Phytopathological Society
Peach is considered "extremely susceptible" to D. tabescens, which attacks even the most healthy and vigorous plants (Rhoads 1950). For example, in the southeastern United States, the disease affects well-managed peach orchards with the same aggressiveness as trees suffering from biotic or abiotic stresses. Claims that ARR caused by $D$. tabescens affects only stressed peach trees (Steiner 1976) lack scientific evidence. Therefore, no tree stress-reducing management options are currently recommended (Cox et al. 2004) or have been proven effective to prevent ARR disease or to slow down disease progression. Many preplant and postplant management strategies were evaluated to manage the disease. Preplant soil fumigation with methyl bromide, sodium thiotetracarbonate, or metam sodium will reduce but do not eliminate inoculum (Adaskaveg et al. 1999; Savage et al. 1974). Postplant infusion of tree trunks with systemic fungicides (Adaskaveg et al. 1999; Amiri and Schnabel 2012) or complete removal of trees neighboring a symptomatic tree will slow down disease progression but are considered economically prohibitive (Adaskaveg et al. 2008). Even multiyear, preventative application of Trichoderma spp. via drenches did not slow down tree mortality on replant sites (Schnabel et al. 2011). The most common rootstocks used in the southeastern United States (Guardian, Halford, Nemaguard, and Lovell) are susceptible (Beckman 1998; Beckman and Pusey 2001; Beckman et al. 1998). Only recently have plum/peach hybrid rootstocks such as MP-29 and Sharpe shown promise in providing resistance (Beckman et al. 2012).

Disease incidence and mortality are particularly severe on replant sites, in part due to an increase in woody roots colonized by mycelium (i.e., inoculum) in the soil from one planting to the next. When commercial orchards become unproductive, trees are removed, 
leaving woody residual roots colonized by the vegetative stage of the pathogen (mycelium). Depending on the size and proximity to the surface of the woody root, and soil moisture and type, the fungus can persist in residual roots from years to decades (Baumgartner and Rizzo 2002; Redfern and Filip 1991). The pathogen continues to utilize dead root tissue as a source of nutrition (Petersen 1961), successfully fending off other competitors. Replanted orchards typically experience symptom expression and mortality earlier (in some cases only 3 years after planting) than orchards planted following nonhost crops.

Physically cutting out infected wood of symptomatic trees and removal of the soil to expose the root crown (i.e., root-collar excavation [RCE]) was first suggested by Rhoads (1950) as a method to prevent the fungus, when already present at the root collar as a mycelial fan beneath the bark, from girdling the trunk of an infected peach tree. RCE then was shown to be an efficient postinfection practice for ARR management in citrus and grapevines by increasing plant longevity and yield in comparison with nonexcavated trees (Baumgartner 2004; Rackham et al. 1966). By excavating soil from around the lower trunk to expose primary roots, mycelial fans of the fungus retreat from the exposed roots due to heating and drying (Munnecke et al. 1976). In a proof-of-concept study conducted in Smart Pots (High Caliper Growing, Oklahoma City, OK, U.S.A.), RCE was used as a preventative measure to reduce tree mortality on replant sites (Schnabel et al. 2012). Trees were planted high enough that, after excavation, the root initiation of primary roots remained above ground. The RCE tree planting system is effective, because $D$. tabescens does not typically grow above the soil line in peach trees under southeastern conditions. Although the pathogen infects roots below ground, further colonization of the root collar is prevented. The objective of this study was to determine the feasibility and efficacy of the RCE tree planting system on a commercial scale and to determine any impact on yield or fruit quality.

\section{Materials and Methods}

Site selection and preparation. Two locations with high (>50\%) peach tree mortality due to ARR disease were selected for this experiment. ARR was positively diagnosed visually in 2010 before trees were removed. Roots of dying trees revealed characteristic white mycelial fans within the bark tissue of the root collar and roots of symptomatic trees. Trees at both locations were removed in 2010. While many roots at the commercial location were 'raked' with a chisel plow, no effort was made to remove infected roots at the experimental station prior to replanting. The soil was not fumigated prior to planting. Replant sites were located in a commercial orchard (Ridge Spring, SC; $33.81463^{\circ} \mathrm{N},-81.68686^{\circ} \mathrm{W}$ ), representing one of the largest growing regions in South Carolina (Ridge), and at Clemson University's Musser Fruit Research Center, Seneca, SC $\left(34.60085^{\circ} \mathrm{N},-82.87293^{\circ} \mathrm{W}\right)$. The soil type in Seneca was a red clay/sand mixture and the soil type in Ridge Spring was primarily sand.

Experimental design and root-collar excavation. Experimental trees were planted in 2011 either as normally planted by growers or on berms. Berms were prepared using a dual-disc levee plow (Savannah Global Solutions, Pembroke, GA, U.S.A.), with a target berm height of $45 \mathrm{~cm}$ and width of $90 \mathrm{~cm}$. Trees were planted shallow on berms (Fig. 1A), ensuring the primary root initiation from the trunk 2 to $4 \mathrm{~cm}$ below the soil line of the berm roof. Trees consisted of 'Redglobe' scion on Guardian rootstock in Seneca and 'Flameprince' scion on Halford rootstock in Ridge Spring. Both rootstocks are susceptible to ARR. In both Ridge Spring and Seneca, trees were trained to the perpendicular- $\mathrm{V}$ system with 1.5 -m-wide spacing between trees and 6-m-wide spacing between rows. The treatments consisted of four rows of 50 trees each at the Ridge Spring location and three rows of 25 trees each at the Seneca location, with "Grower Standard" and RCE treatment rows alternated. Two years after establishment, the root collars were excavated on trees on berms using, first, a standard hoe to remove soil near the roots (at an approximately $80-\mathrm{cm}$ radius from the trunk), followed by an AirSpade 2000 Arborist/ Landscaper Kit-105 cfm (Guardair Corporation, Chicopee, MA, U.S.A.) to remove the soil surrounding the lower trunk and root collar (at an approximately $80-\mathrm{cm}$ radius from the trunk and $25-\mathrm{cm}$ soil depth; Fig. 1B). The airspade was powered by a commercial-grade air compressor. Enough soil was removed to expose 5 to $10 \mathrm{~cm}$ of the sections of primary roots extending out from the root collar (Fig. 1C).
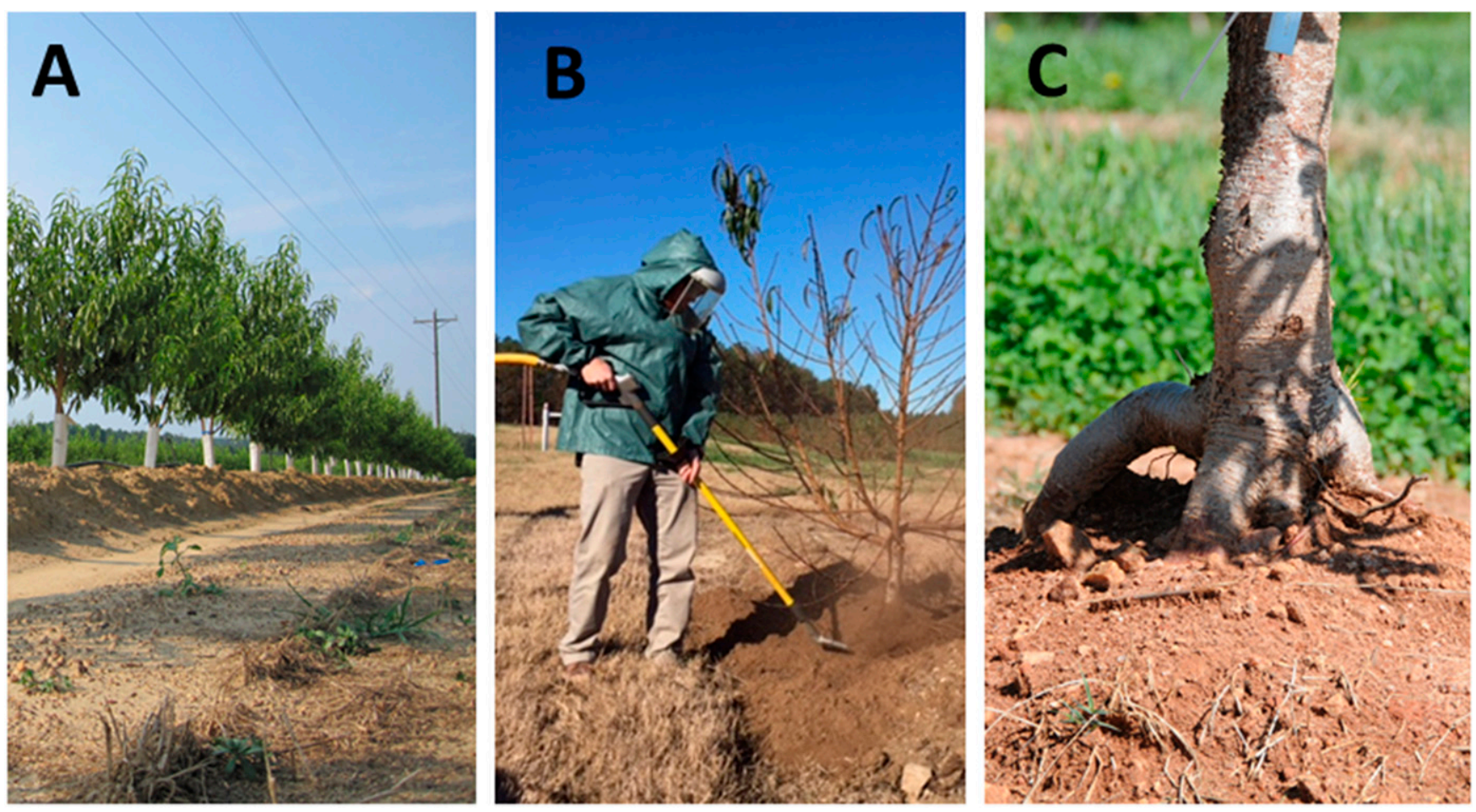

Fig. 1. Steps in the establishment of the root-collar excavation tree planting system to grow peach trees on replant sites. A, Peach trees planted shallow on berms; $\mathbf{B}$, excavation of root collar using an AirSpade; and $\mathbf{C}$, tree with excavated root collar. 
Trees were evaluated each year at the phenological stage of pit hardening (in early summer) for mortality, which was attributed to ARR if the white mycelial fans (diagnostic sign of ARR) were visually located within the bark of the lower, subterrestrial trunk. Mortality from bacterial canker was characterized by scion death, with scaffold limbs and trunk sections revealing sharp demarcation zones between necrotic and nonnecrotic tissue, and a living rootstock, which did not show signs of ARR (bacterial canker was observed only in Ridge Spring). In Seneca, trunk diameters of nonsymptomatic trees were measured 10 to $15 \mathrm{~cm}$ above the graft union during each dormant season using a forestry D-tape.

Five arbitrarily selected, asymptomatic trees in full production were selected within each experimental replicate (row). In Seneca, fruit were harvested at commercial maturity over three harvests in 2018 (6 July, 10 July, and 13 July) and two harvests in 2019 (3 July and 8 July). Total fruit yield was determined as the sum total yield (in kilograms) per tree. Five fruit from each of the five trees collected from the second harvest in 2018 and the first harvest in 2019 were used for fruit quality measurements and phenotyped according to Frett et al. (2012). In Ridge Spring, five fruit from each of the five trees were collected from the middle harvest only on 7 August 2018 and 12 August 2019. Fruit diameter (in millimeters), mass (in grams), and fruit firmness (in kilograms) were measured using a fruit texture analyzer (GÜSS Manufacturing [Pty.] Ltd., South Africa), equipped with an electronic fruit size measurement device and electronic scale. The juice from five fruit was collected to determine soluble solids concentration (SSC), $\mathrm{pH}$, and titratable acidity (TA). SSC ( ${ }^{\circ}$ Brix) was measured using a digital refractometer (Atago 3810 PAL-1, Bellevue, WA, U.S.A.), and pH and TA (percent malic acid) were assessed using an 862 Compact Titrosampler (Metrohm, Riverview, FL, U.S.A.).

Statistical analysis. For tree mortality, data were calculated as a percentage of total trees that died per row. Data were analyzed with JMP (version 14; SAS Institute, Cary, NC, U.S.A.). An analysis of variance (ANOVA) was utilized, with treatment, year, and the interaction term considered as fixed effects and row nested within treatment included as a random effect. ANOVAs were performed for trunk diameter, yield, and fruit quality traits within each year, with treatment considered as a fixed effect and row nested within treatment included as a random effect. Assumptions of ANOVA were satisfied using a Welch test, and statistical significance was defined as $P<0.05$. For all significant ANOVAs, Fisher's protected least significant difference test was conducted to determine separation of means.

Profitability Analysis. Following Egea et al. (2017) and Hester and Cacho (2003), the net present value (NPV) for each practice (i) was calculated as:

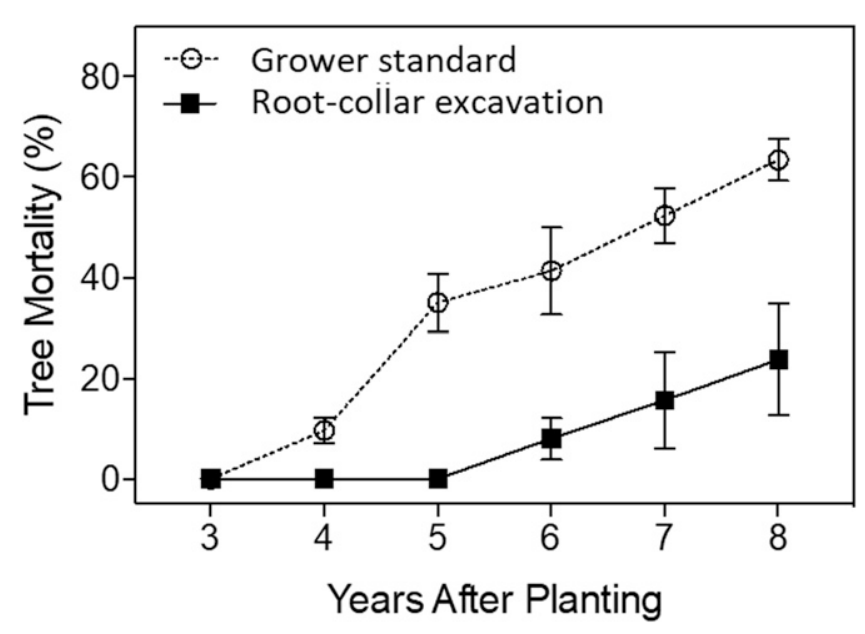

Fig. 2. Annual mortality of peach trees in the Seneca location due to Armillaria root rot in the Grower Standard and root-collar excavation treatments.

$$
\mathrm{NPV}_{\mathrm{i}}=-\mathrm{CE}_{i}+\sum_{t=1}^{T} \frac{\text { Net Cash Flow }}{t i}
$$

where $C E_{i}$ is the establishment cost of the peach orchard, for each practice (i), starting with bare ground; $t$ is the number of periods; $r$ is the discount rate; and Net Cash Flow represents the orchard's expected net cash inflow at each time period (revenue - expenses, including noncash expenses such as depreciation).

Information about the potential establishment costs, costs per year, and revenue were obtained from Florida peach enterprise budgets (Singerman et al. 2017). The Florida peach enterprise budgets were preferred over the South Carolina budgets (White 2019) because they include additional information such as variable irrigation costs. The budgets were modified to include the additional cost for RCE establishment. For the objectives of this study, we assumed a price of $\$ 5.24 / \mathrm{kg}$ of fruit $(\$ 2.38 / \mathrm{lb}$.) and $8,182 \mathrm{~kg} / \mathrm{ha}(7,300 \mathrm{lb} . / \mathrm{acre})$ marketable yield from years 4 through 8 (Singerman et al. 2017). We did not include marketing and packaging costs in the analysis. Following previous similar research endeavors (Sgroi et al. 2015), we assumed a 5\% discount rate. Furthermore, in line with the Florida budget, the NPV calculations were based on 40.5 ha (100 acres) and 385 trees/ha (156 trees/acre).

Considering that the estimated revenues and expenses are a function of the tree density, which fluctuates between the two approaches, the Florida enterprise budgets were used to estimate the variable cost per hectare and total yield for different numbers of trees per hectare before calculating the NPV per hectare (Hester and Cacho 2003). For the purposes of the present study, we made the following assumptions. For the Seneca location, tree mortality was $8 \%$ starting at year 6 for the RCE treatment and 12.7\% starting at year 4 for the Grower Standard treatment. For the Ridge Spring location, tree mortality was $1.9 \%$ starting at year 7 for the RCE treatment and $4.3 \%$ starting year 5 for the Grower Standard treatment. A constant yield per tree was assumed in each of the two treatments regardless of the mortality rate.

\section{Results}

Assessment of tree mortality, yield, and fruit quality parameters. Tree mortality in the RCE treatment of the experimental orchard near Seneca was first observed in year 6 and increased at a rate of about $8 \%$ per year to reach $24.0 \%$ in year 8 . In contrast, tree mortality in the Grower Standard treatment was first observed in year 4 and increased at a rate of $12.7 \%$ per year to reach $63.3 \%$ in year 8 (Fig. 2). At the commercial orchard near Ridge Spring, tree mortality in the RCE treatment was first observed in year 7 and increased at a rate of $1.9 \%$ to reach $3.7 \%$ in year 8 , whereas tree mortality in the Grower Standard treatment first

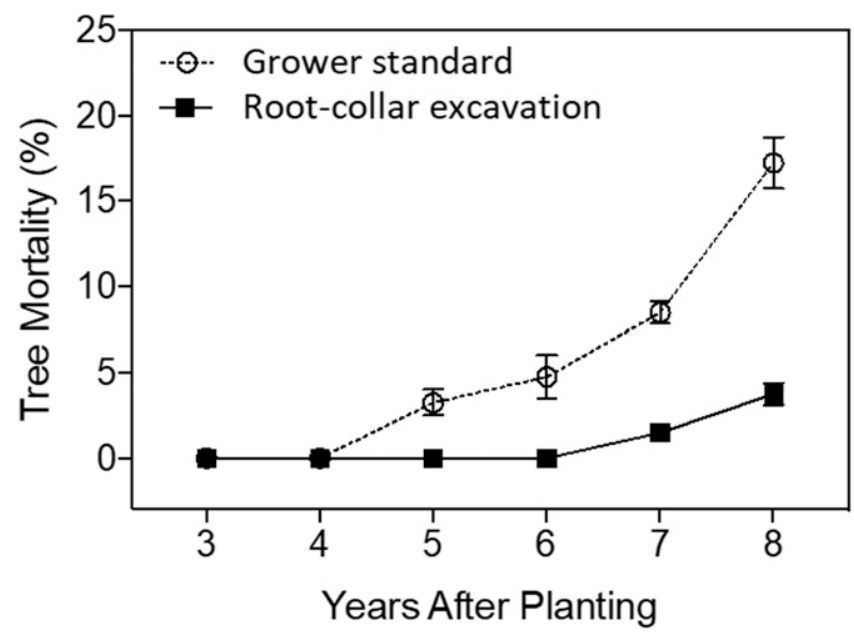

Fig. 3. Annual mortality of peach trees in the Ridge Spring location due to Armillaria root rot in the Grower Standard and root-collar excavation treatments. 
occurred in year 5 and increased at a rate of $4.3 \%$ to reach $17.3 \%$ in year 8 (Fig. 3). In the Ridge Spring location, bacterial canker also caused tree mortality. However, data analysis revealed no statistical differences between RCE and Grower Standard treatments in tree mortality (Fig. 4).

Tree trunk diameters increased from 2018 to 2019 in both treatments; however, between treatments, there were no significant differences in any of the years evaluated $(P<0.05)$ (Table 1). Although yields in 2019 were slightly reduced in both treatments in both locations compared with yields of the respective treatment of the previous year, no significant differences were found between treatments. In the Seneca location, fruit mass, firmness, $\mathrm{SSC}, \mathrm{pH}$, and TA ranged from 172.2 to $202.94 \mathrm{~g}, 3.92$ to $5.23 \mathrm{~kg}, 11.84$ to $12.45{ }^{\circ}$ Brix, 3.45 to 3.71 , and 0.64 to $0.65 \%$, respectively, but no significant differences were found between treatments $(P<0.05)$ (Table 1). In the Ridge Spring location, fruit mass, firmness, $\mathrm{SCC}, \mathrm{pH}$, and TA ranged from 178.3 to $250.1 \mathrm{~g}, 4.98$ to $60.5 \mathrm{~kg}, 11.01$ to $12.04{ }^{\circ} \mathrm{Brix}, 3.34$ to 3.57 , and 0.83 to $0.9 \%$, respectively, but no significant differences were found between treatments $(P<0.05)$ (Table 1).

The results of the NPV estimation indicate that the profitability of the RCE treatment was higher at both locations 8 years into orchard establishment, compared with the Grower Standard. However, the difference between the two treatments was substantially less in the Ridge Spring location (Table 2). After 8 years, the NPV of the RCE treatment in the Seneca location was almost double $(\$ 42,250.51)$

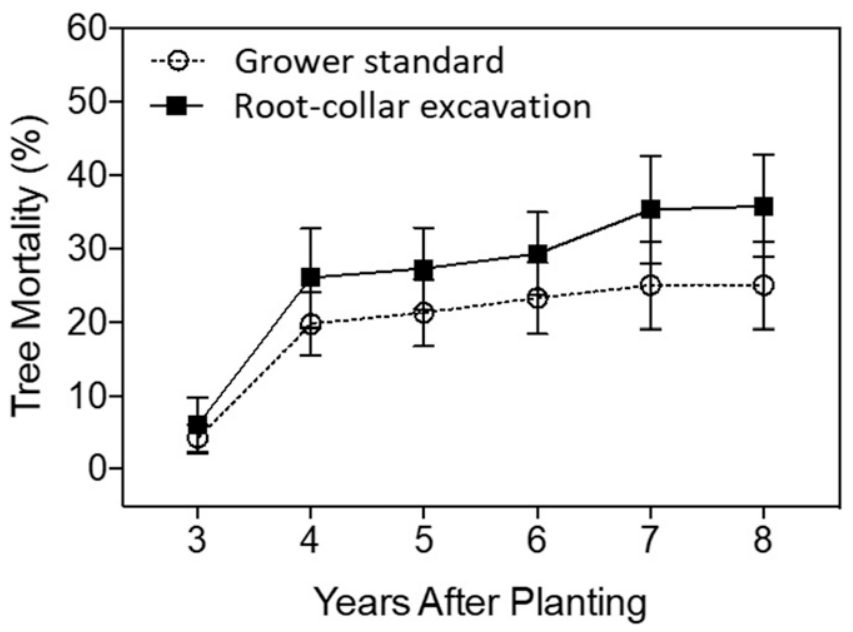

Fig. 4. Annual mortality of peach trees in the Ridge Spring location due to bacterial canker in the Grower Standard and root-collar excavation treatments. compared with the NPV value for the Grower Standard (\$22,510.03). In contrast, the NPV of the RCE treatment in the Ridge Spring location was only $8.1 \%$ higher compared with the Grower Standard (Table 2). Assuming a linear tree mortality rate at both locations, the NPVs would remain higher for the RCE in both locations. The NPV of the RCE treatment in the Seneca location would again be almost double that of the Grower Standard treatment, whereas the same value was calculated to be $14 \%$ higher in the Ridge Spring location (Table 2).

\section{Discussion}

If soil becomes contaminated by an aggressive soil- or root-borne pathogen that is difficult to control and which increases in density over time, the land may have to be abandoned for cropping (Stover 1959; Tims 1953) or may have to be cropped with a nonhost crop unsuited for the farm's business model or equipment. D. tabescens inoculum can accumulate in the soil over time if infection centers expand or after generations of peach orchards have increased the inoculum level to a degree that premature peach tree mortality threatens the profitability of the land. Our findings of a 2-year delayed onset of tree mortality and up to $55.8 \%$ annual reduction of tree mortality shows that the RCE tree planting system extends the productive life of a peach orchard on replant sites with high ARR inoculum pressure. Tree mortality may likely be slowed down further if preventative RCE is combined with preplant reduction of inoculum via mechanical root removal (root raking) or soil fumigation (Adaskaveg et al. 1999). Furthermore, our data show that asymptomatic trees with exposed root collars produced similar yields and fruit quality compared with trees grown according to the Grower Standard, indicating no commercially relevant negative physiological side effect on the tree.

Many southeastern growers have adopted the idea of this modified planting system but implementation has its challenges. Some growers are not able to make a high-enough berm with the available farm equipment or plant trees too deep into the berm. Both make subsequent efforts to excavate the root collar very difficult. Within the first year of planting, wind may move trees to lean if planted in a location with strong winds or if they are subject to unusually high-wind storms due to the shallow, not-yet-well-established root system. In such at-risk locations, a grower may choose to temporarily stake trees. Although not yet observed on a commercial scale, the shallow root system may also lead to trees experiencing drought stress during the first year of establishment in case of insufficient rainfall and lack of irrigation.

Waiting for 2 years instead of 1 year before excavating the root collar has several advantages. First, the excavated roots will have matured sufficiently and are no longer susceptible to wind and herbicide uptake. In a study sponsored by the South Carolina Peach Council, the newly exposed root collars resisted exposure to common herbicides

Table 1. Yield and fruit quality of the Grower Standard (GrS) and root-collar excavation (RCE) treatments in orchards near Ridge Spring ('Flameprince' on Halford) and Seneca ('Redglobe' on Guardian) in 2018 and 2019

\begin{tabular}{|c|c|c|c|c|c|c|c|}
\hline Treatment $^{b}$ & Total yield (kg/tree) & Diameter (mm) & Mass (g) & Firmness (kg) & $\operatorname{SSC}\left({ }^{\circ} \mathbf{B r i x}\right)^{\mathbf{c}}$ & pH & Malic acid (\%) \\
\hline \multicolumn{8}{|l|}{$\overline{\text { Seneca }}$} \\
\hline \multicolumn{8}{|l|}{2018} \\
\hline GrS & $43.13 \pm 8.2$ & $68.74 \pm 5.9$ & $172.2 \pm 46.3$ & $5.23 \pm 0.6$ & $12.18 \pm 0.6$ & $3.64 \pm 0.1$ & $0.65 \pm 0.1$ \\
\hline RCE & $42.33 \pm 6.3$ & $70.41 \pm 4.6$ & $183.73 \pm 35.0$ & $5.13 \pm 0.7$ & $11.84 \pm 0.4$ & $3.71 \pm 0.1$ & $0.64 \pm 0.1$ \\
\hline \multicolumn{8}{|l|}{2019} \\
\hline GrS & $34.29 \pm 2.0$ & $70.58 \pm 5.0$ & $182.54 \pm 34.4$ & $4.79 \pm 1.0$ & $12.45 \pm 0.7$ & $3.48 \pm 0.1$ & $0.57 \pm 0.1$ \\
\hline RCE & $37.05 \pm 10.8$ & $74.06 \pm 3.2$ & $202.94 \pm 33.1$ & $3.92 \pm 1.3$ & $12.09 \pm 1.0$ & $3.45 \pm 0.1$ & $0.57 \pm 0.1$ \\
\hline \multicolumn{8}{|l|}{ Ridge Spring } \\
\hline \multicolumn{8}{|l|}{2018} \\
\hline GrS & $\ldots$ & $79.13 \pm 3.6$ & $245.10 \pm 31.4$ & $5.23 \pm 0.6$ & $11.01 \pm 0.6$ & $3.57 \pm 0.1$ & $0.83 \pm 0.1$ \\
\hline $\mathrm{RCE}$ & $\ldots$ & $79.61 \pm 2.3$ & $250.11 \pm 19.1$ & $4.98 \pm 0.6$ & $11.07 \pm 0.5$ & $3.54 \pm 0.1$ & $0.86 \pm 0.1$ \\
\hline \multicolumn{8}{|l|}{2019} \\
\hline GrS & $\ldots$ & $72.31 \pm 4.0$ & $178.28 \pm 47.3$ & $6.05 \pm 0.5$ & $12.04 \pm 0.5$ & $3.39 \pm 0.1$ & $0.88 \pm 0.1$ \\
\hline $\mathrm{RCE}$ & $\ldots$ & $71.80 \pm 2.6$ & $192.89 \pm 33.3$ & $5.87 \pm 0.7$ & $12.04 \pm 0.7$ & $3.34 \pm 0.1$ & $0.90 \pm 0.1$ \\
\hline
\end{tabular}

a Data are presented as means and standard deviations of five fruit arbitrarily selected from five asymptomatic trees in full production. Fisher's protected least significant difference test $(P>0.05)$ was used to determine separation of means. The lack of letters in each column indicates no significant differences.

${ }^{\mathrm{b}}$ Location, year, and treatment.

${ }^{c}$ Soluble solids concentration. 
Table 2. Net present value (NPV) calculations for the Grower Standard and the root collar excavation (RCE) treatments at two locations in South Carolina (Seneca and Ridge Spring)

\begin{tabular}{|c|c|c|c|c|}
\hline \multirow[b]{2}{*}{ Location } & \multicolumn{2}{|c|}{ Seneca } & \multicolumn{2}{|c|}{ Ridge Spring } \\
\hline & Grower Standard & RCE & Grower Standard & RCE \\
\hline NPV/ha 8 years & $\$ 22,510.03$ & $\$ 42,250.51$ & $\$ 45,502.16$ & $\$ 49,523.30$ \\
\hline NPV/ha 12 years $^{\mathrm{a}}$ & $\$ 38,566.42$ & $\$ 74,928,91$ & $\$ 85,807.95$ & $\$ 99,704.15$ \\
\hline
\end{tabular}

${ }^{\text {a }}$ For the 12th-year calculation, we used averaged annual tree mortality percentages according to orchard location and treatment.

and no impact on tree health was detected (Schnabel et al. 2015). After excavation, growers noticed increased suckering of some rootstocks such as Guardian. This requires the pruning crew to spend more time in the orchard and increases labor expense for the farm owner. Some growers, however, choose a cheaper alternative and "chemically burn" the suckers with a nonsystemic herbicide. The berms themselves pose some challenges as well. Apart from the inconvenience to orchard workers from having to climb up and down the berm during pruning, thinning, or harvest, the berm can also channel surface rainwater and increase erosion due to the quicker runoff along the sides of the berms. One solution to this problem is to install waterways between trees and within tree rows to allow water to pass through. The same strategy can be applied if berms trap water in low-lying terrain, which might cause waterlogging. Another is to avoid creating deep furrows next to the berm by using a multidisc levee plow that collects the soil for berm formation from a wider area. When root collars are excavated, however, surface water can better distribute between rows and thus runoff becomes less of a problem.

In addition to its biological benefits, described earlier, the RCE treatment will also influence the cost, and potentially the profitability, of the peach orchard over its lifetime. For example, the manager must pay additional cost for the establishment of the berm or excavation of tree roots. Considering that financial performance is one of the most critical factors when orchard managers select their preferred practices (Hester and Cacho 2003; Lordan et al. 2019; Sgroi et al. 2015), evaluating the profitability of RCE vis-à-vis the Grower Standard approach is critical. Several different options have been used in the literature to evaluate the economic performance of different production practices in orchards. However, the most commonly employed technique for financial comparison is the NPV (Hester and Cacho 2003). Despite its limitations due to assumptions made such as orchard-specific number of trees per hectare, yield per hectare, and the cost structure of every orchard, the basic profitability analysis provided insights into the effects of RCE versus Grower Standard treatments. The analysis indicated a higher NPV for the RCE treatment at the time of the end of the experiment ( 8 years) and also predicted higher NPV values at year 12 . These financial results of the RCE treatment are highly dependable on the tree loss percentages and when loss first appear. The Seneca location, exhibiting the highest disease pressure, financially benefited the most from the RCE treatment and produced an NPV that was about double that of the Grower Standard 8 and 12 years after planting. The same analysis only indicated a moderate increase in NPV at the Ridge Spring location, where disease pressure was substantially lower.

Whether preventative RCE will reduce ARR of peach elsewhere or in other susceptible woody plants is not clear. Peach fruit is produced in California, Colorado, Michigan, New Jersey, Pennsylvania, and other nonsouthern states but, in those states, ARR is not reported to be a major problem. This may be because the disease is caused by geographically isolated Armillaria spp., which may not be as virulent on peach compared with $D$. tabescens (Rhoads 1950). For example, ARR on Prunus spp. in California is caused by A. mellea (Adaskaveg et al. 1999) and in Michigan by A. solidipes Peck (formerly known as A. ostoyae) (Devkota and Hammerschmidt 2019). However, there are other woody crops known to be vulnerable to ARR. They include Prunus tree crops, nut crops, and grapevines in California (Adaskaveg et al. 1999; Baumgartner 2004; Gardner and Raabe 1963; Raabe 1962) as well as tart cherry trees in Michigan (Proffer et al. 1987). Whether preventative RCE can reduce tree mortality in these crops will largely depend on whether the ARRcausing pathogen is capable of growing above the soil line. Only one study has shown postsymptomatic use of RCE to be effective on grapevines (Baumgartner 2004).

Considering the potential drawbacks of RCE and the lack of other management options on replant sites, only peach growers in those regions may want to choose the RCE tree planting system to delay ARR-associated tree mortality in orchards with high ARR inoculum pressure. Such locations include replant sites where ARR had caused significant tree mortality in previous peach crops and sites that are cleared for peach production but that recently were in ARRinfested forest land. As documented in this study, the RCE system does not protect from other diseases such as bacterial canker (Fig. 4). However, personal observations by the authors suggest that trees planted on berms may be less susceptible to trunk cracking by cold injury. In one orchard that was not part of this study, bermed trees were planted next to Grower Standard trees and only Grower Standard trees revealed trunk cracks that later served as entry ports for Oxyporus rot. In conclusion, RCE applied preventatively to newly established orchards increases tree longevity in orchards with high ARR pressure.

\section{Literature Cited}

Adaskaveg, J. E., Foerster, H., Wade, L., Thompson, D. F., and Connell, J. H. 1999 Efficacy of sodium tetrathiocarbonate and propiconazole in managing Armillaria root rot of almond on peach rootstocks. Plant Dis. 83:240-246.

Adaskaveg, J. E., Schnabel, G., and Foerster, H. 2008. Diseases of peach caused by fungi and fungal-like organisms: Biology, epidemiology and management. Pages 352-406 in: The Peach. D. R. Layne and D. Bassi, eds. CABI, Wallingford, Oxfordshire, U.K

Amiri, A., and Schnabel, G. 2012. Persistence of propiconazole in peach roots and efficacy of trunk infusions for Armillaria root rot control. Int. J. Fruit Sci. 12: 437-449.

Baumgartner, K. 2004. Root-collar excavation for postinfection control of Armillaria root disease of grapevine. Plant Dis. 88:1235-1240.

Baumgartner, K., and Rizzo, D. M. 2002. Spread of Armillaria root disease in a California Vineyard. Am. J. Enol. Vitic. 53:197-203.

Beckman, T. G. 1998. Developing Armillaria resistant rootstocks for peach. Acta Hortic. 465:219-224.

Beckman, T. G., Chaparro, J. X., and Sherman, W. B. 2012. 'MP-29', a clonal interspecific hybrid rootstock for peach. HortScience 47:128-131.

Beckman, T. G., Okie, W. R., Nyczepir, A. P., Pusey, P. L., and Reilly, C. C. 1998 Relative susceptibility of peach and plum germplasm to armillaria root rot. HortScience 33:1062-1065.

Beckman, T. G., and Pusey, P. L. 2001. Field testing peach rootstocks for resistance to Armillaria root rot. HortScience 36:101-103.

Cox, K. D., Scherm, H., and Beckman, T. G. 2004. Armillaria root rand crown rot Pages 162-166 in: Southeastern Peach Grower's Handbook. D. Horton and D. Johnson, eds. University of Georgia, College of Agricultural and Environmental Sciences, Athens, GA, U.S.A.

Devkota, P., and Hammerschmidt, R. 2019. A rapid and holistic approach to screen susceptibility of Prunus species to Armillaria root rot. For. Pathol. 49:e12547.

Egea, G., Fernadez, J. E., and Alcon, F. 2017. Financial assessment of adopting irrigation technology for plant-based regulated deficit irrigation scheduling in super high-density olive orchards. Agric. Water Manage. 187:47-56.

Frett, T., Gasic, K., Clark, J., Byrne, D., Gradziel, T., and Crisosto, C. 2012 Standardized phenotyping for fruit quality in peach [Prunus persica (L.) Batsch]. J. Am. Pomol. Soc. 66:214-219.

Gardner, M. W., and Raabe, R. D. 1963. Early references to Armillaria root rot in California. Plant Dis. Rep. 47:413-415.

Hester, S. M., and Cacho, O. 2003. Modelling apple orchard systems. Agric. Syst 77:137-154.

Koch, R. A., Wilson, A. W., Sene, O., Henkel, T. W., and Aime, M. C. 2017. Resolved phylogeny and biogeography of the root pathogen Armillaria and its gasteroid relative, Guyanagaster. BMC Evol. Biol. 17:33. 
Lordan, J., Gomes, M., Francescatto, P., and Robinson, T. L. 2019. Long-term effects of tree density and tree shape on apple orchard performance, a 20-year study-Part 2, economic analysis. Sci. Hortic. (Amsterdam) 244:435-444.

Munnecke, D. E., Wilbur, W. D., and Darley, E. F. 1976. Effect of heating or drying on Armillaria mellea and Trichoderma viride and the relation to survival of A. mellea in soil. Phytopathology 66:1363-1368.

Petersen, D. H. 1961. The pathogenic relationship of Clitocybe tabescens to peach trees. Phytopathology 51:819-823.

Proffer, T. J., Jones, A. L., and Ehret, G. R. 1987. Biological species of Armillaria isolated from sour cherry orchards in Michigan. Phytopathology 77:941-943.

Raabe, R. D. 1962. Host list of the root rot fungus, Armillaria mellea. Hilgardia 33: 25-88.

Rackham, R. L., Wilbur, W. D., Miller, M. P., and Paulus, A. O. 1966. Control of oak root rot fungus in citrus. Univ. Calif. Agric. Ext. Serv. Calif. Plant Dis. 26:2.

Redfern, D. B., and Filip, G. M. 1991. Inoculum and infection. Pages. 48-61 in: Armillaria Root Disease. C. G. Shaw, III and G. A. Kile, eds. U.S. Dep. Agric. For. Serv. Agric. Handb. 691.

Rhoads, A. S. 1945. A comparative study of two closely related root-rot fungi, Clitocybe tabescens and Armillaria mellea. Mycologia 37:741-766.

Rhoads, A. S. 1950. Clitocybe root rot of woody plants in the southeastern United States. U.S. Dep. Agric. Circ. 853.

Savage, E. F., Hayden, R. A., and Futral, J. G. 1974. Effect of soil fumigants on growth, yield and longevity of Dixired peach trees. Univ. Ga. Coll. Agric. Exp. Stn. Res. Bull. (Int. Comm. Northwest Atl. Fish.) 148.

Schnabel, G., Agudelo, P., Henderson, G. W., and Rollins, P. A. 2012. Aboveground root collar excavation of peach trees for Armillaria root rot management. Plant Dis. 96:681-686.
Schnabel, G., Ash, J. S., and Bryson, P. K. 2005. Identification and characterization of Armillaria tabescens from the southeastern United States. Mycol. Res. 109: 1208-1222.

Schnabel, G., Mitchem, W., and Henderson, G. W. 2015. Peach disease issues: Development of sustainable options for South Carolina. S. C. Peach Counc. Res. Rep. 15:82-92.

Schnabel, G., Rollins, P. A., and Henderson, G. W. 2011. Field evaluation of Trichoderma spp. for control of Armillaria root rot of peach. Plant Health Prog. 12.

Sgroi, F., Candela, M., Di Trapani, A. M., Fodera, M., Squatrito, R., Testa, R., and Tudisca, S. 2015. Economic and financial comparison between organic and conventional farming in Sicilian lemon orchards. Sustainability 7: 947-961.

Singerman, A., Burani-Arouca, M., and Olmstead, M. 2017. Establishment and Production Costs for Peach Orchards in Florida: Enterprise Budgets and Profitability Analysis. Food and Resource Economics Department, University of Florida IFAS Ext. Publ. FE1016. https://edis.ifas.ufl.edu/fe1016

Steiner, P. W. 1976. White root rot: A threat to the Missouri peach industry. Trans Ill. State Hortic. Soc. 110:24-28.

Stover, R. H. 1959. Growth and survival of root disease fungi in soil. Pages 339-355 in: Plant Pathology: Problems and Progress 1908-1958. C. S. Holton, G. W. Fischer, R. W. Fulton, H. Hart, and S. E. A. McCallan, eds. University of Wisconsin Press, Madison, WI, U.S.A.

Tims, E. C. 1953. Pink root of shallots, Allium ascalonicum. Plant Dis. Rep. 57 533-537.

White, C. 2019. An Economic Contribution and Investment Analysis of the South Carolina Peach Industry. M.Sc. thesis, Clemson University, Clemson, SC, U.S.A 